\title{
UTILIZATION OF REVERTED TAX DELINQUENT LAND IN RURAL AREAS
}

\author{
PAUL W. WAgER*
}

A short time ago a county official said to the writer, "The only way this county can keep going is to keep all the land in private ownership, and if the owners are not able to pay the taxes every year they may at least pay them some years, and if they cannot pay the full tax we should accept a partial payment." In this statement the official casually but accurately epitomized the philosophy which still prevails with respect to land ownership and land taxes. Many people apparently do not realize that as this country approaches a stationary population land must be valued on its productive capacity and not by capitalizing an expected increment. Moreover, the margin of cultivation for agriculture is being steadily contracted, and nonagricultural land must be put to other productive use if it is to make its full contribution to the support of population. Private capital, having exploited our natural resources, may not be willing or able to undertake the renewal of these resources and to carry the investment during the long waiting period. The retention of nonincome-producing land in private ownership almost invariably leads either to the collapse of the tax collecting procedure or to the further destruction of the resource. Certainly it operates against the conversion of the land to new uses and the restoration of economic stability.

To urge the retention of all land in private ownership in order to preserve sufficient tax base to support local government overlooks two important facts. First, in a county with diminishing resources the tax base is being reduced regardless of what is listed on the tax roll, and taxes cannot continue indefinitely to be paid out of capital. Second, there is no need to perpetuate every political unit established to meet conditions of an earlier period. If our natural resources are to be renewed and conserved and each type of land put to its best use, tax policies must be shaped to that end. This does not necessitate the granting of subsidies; it requires only the proper recognition of the use-capabilities of different grades of. land and their valuation for taxation accordingly. It also demands an easy and direct means of

- B.S., I917, Hobart College; A.M., I920, Haverford College; Ph.D., 1927, University of North Carolina. Associate Professor of Rural Social Economics, University of North Carolina since rg28. On leave at present serving as Chief, Land Use Planning Section, Resettlement Administration, Region IV. Author: County Government and Administration in North Carolina (Chapel Hill, 1928). 
transfer from private to public ownership when the private owner is unwilling or unable to assume the responsibilities of ownership.

\section{Much Land Unsuited to Private Ownership}

There is a vast acreage of land in the United States that is better suited to forestry than to any other use. Some of this occupies such extensive areas that it should be purchased and administered as national forests. Already $x 70$ million acres are in federal ownership, but there is much blocking-in which needs to be done, both in the interest of efficient administration and sound land use. There are many slightly less extensive areas of forest land which lend themselves to state or municipal ownership. Public ownership is preferable to private ownership when a watershed needs to be protected or when the time and cost involved in getting the forest on a sustained yield basis are too great to attract private capital.

Similarily there are areas now largely in farms which are more suitable for grazing, or for wild life preserves, or for recreational development. To block up these areas and then develop and administer them in the public interest is a task for government rather than private enterprise. It is not suggested that all major adjustments in land use must wait upon public ownership. It is evident, however, that in many cases it is the only means of checking the wastage of our soil and forest resources.

\section{Tax Delinquency Not Always Involuntary}

Tax delinquency may be due to various causes, but chronic delinquency frequently accompanies a transition in land use and unstable ownership. Not all tax delinquency is involuntary. If one owns property the original cost of which has been recovered or property which is not yielding an annual income, his promptness in paying taxes is likely to be determined more by the diligence with which collections are prosecuted than by his financial circumstances. A reasonably prompt foreclosure would force him to decide whether to raise the taxes or surrender the property. Even where delinquency is involuntary, less hardship would result from prompt and vigorous enforcement of the tax lien than might be supposed. Taxes on productive property could generally be paid out of income if the owner knew in advance that there was no alternative and made preparations. The owner of unproductive or deferred-yield property must of course pay the taxes out of other income or out of capital. Presumably he expected to do this when he acquired the property. If his own resources fail him in a particular year, he should have no difficulty in borrowing the amount of the taxes with the property as security. If the property were already encumbered, the mortgage-holder would, of course, have to advance the taxes to protect his equity. The government would either get the taxes or the property; it would cease being an extender of credit. The effect viewed from the taxpayer's angle would be that some properties owned by people operating on a shoe-string would be 
transferred to stronger shoulders and some deferred-yield properties would revert to the state or county.

\section{Reversion Checked by Depression Legislation ${ }^{1}$}

The large volume of delinquency which appeared as a product of the depression prompted the legislatures of many states to authorize compromise settlements. Others waived penalties or declared moratoria on tax foreclosures. While most of these concessions were temporary, their demoralizing effect will long be felt. Moreover, they interrupted, even prevented, the transfer to public ownership of lands voluntarily abandoned by private owners. It is estimated that at least four million acres of cut-over land in Minnesota was subject to state title in I933 when the legislature extended the redemption period from five to seven years. ${ }^{2}$ Similar stays were granted in Oregon, Washington, North Carolina and many other states.

In North Carolina there is no state property tax and land bid in by the county at tax sale may be foreclosed after two years. Although the county can secure a good title there are only scattered instances where it has done so. The legislature of 1935 authorized a certain county to appoint an adjustment committee with authority to compromise the taxes of 1932 and prior years. ${ }^{3}$

A certain land and timber company owned something over 14,000 acres of cut-over land on which it had paid no taxes for I 926 or any year subsequent. 'The seven years' taxes, exclusive of interest and penallies, amounted to $\$ 3,184$. The committee accepted a cash settlement of $\$ \mathrm{r}, 592$, or just half of the original tax. Had the compromise not been authorized the county could have taken title to the land along with perhaps I00,000 acres of land of similar quality. Had the property been likely to become taxpaying regularly hereafter, there might have been some justification for not having taken title. But most of it will continue to be delinquent in expectation of cancessions again, and other taxpayers, hitherto punctual, will join the procession in self-defense.

\section{State Title Often Worthless}

One reason why political units have been reluctant to enforce the tax lien is that they have been unable to get a good title to the property. In many states reversion is only nominal; the former owner possesses an indefinite right of redemption and frequently he can redeem at less cost than the accrued taxes.

In Mississippi, lands that have matured to the state may be redeemed by the owner at any time after maturity date by the payment of the taxes, plus damages (penalties) and six per cent interest for the year the property was sold for taxes. The state may acquire valid title to land maturing for non-payment of taxes only when the general public, including the owner at the time of tax sale, is favorable to the land being sold or dedicated by the Governor to a public use. Dedication might

\footnotetext{
${ }^{2}$ For a discussion of this legislation see Smith, Recent Legislative Indulgences to Delinquent Taxpayers, supra, p. 371.

Minn. Laws r933; c. 98, p. 104.

-N. C. Lams 1935, Pub. Local No. 413.
} 
be accomplished by virtue of an act providing for a commission to survey lands owned by the state to determine their adaptability for use as state parks, game and fish preserves and state forests. ${ }^{4}$ Findings of the survey must be submitted to the board of supervisors of the county in which the lands are located, and no transfer and dedication to state use can be effected without the approval of the board of supervisors after a hearing to which the former owner is invited. To date, no land has actually been dedicated in this way.

In Louisiana, land offered at tax sale and failing to attract a private bidder is adjudicated to the state and a list. of such properties, together with the amount of taxes and costs, is filed by the sheriff with the State Land Office. 5 However, the state does not obtain a title to the land, merely holding a claim against it to the amount for which it was adjudicated. The owner may redeem the property at any time by paying the state its claim, that is, a single year's taxes plus the advertising and selling costs. Anyone may request that a specified piece of unredeemed property be advertised and offered for sale by simply making a $\$ 25$ deposit. The amount bid at such sale must equal the amount for which the property was assessed on the tax roll. If such an amount is not bid the property may be appraised and again advertised for sale. "It is possible," says a Louisiana commentator, "that land adjudicated fifty years ago for non-payment of taxes may have been used for personal gain throughout the entire period without the State having the benefit of any taxes."

A recent study revealed that on November 15, I934 there were 3,44x,860 acres which had been adjudicated to the state and not redeemed. However, the state has set up no agency whose function it is to locate the adjudicated land, to determine the use being made of it, and to classify it for present or future use; neither is the delinquent taxpayer evicted from the land.

In Florida, at the present time neither the state nor the counties can take title to tax delinquent lands. In r929 a statute was passed which provided that the county tax collectors should sell land on which the taxes were unpaid at public auction, and in case there were no private bidders of a sufficient sum to pay the full amount of the decree, including interest and subsequent costs, the title to the land should be transferred to the Trustees of the Internal Improvement Fund. ${ }^{8}$ This body, acting for the State of Florida, could hold or dispose of such land as it saw fit. However, this statute was repealed at the 1935 session of the Florida Legislature, ${ }^{7}$ and since then has not been operative.

The trustees now have holdings, acquired under the 1929 act, located in four counties and consisting of 31,260 acres and 177 lots. These lands will await such disposition as the Trustees may see fit, and as is in accordance with authority vested in them. Their policy to date has been to assist the original owners to reacquire their land upon payment of delinquent taxes. Where application has been made by

-Miss. Ans. Code (Hemingway, 1930) \$4750.

'Fla. Comp. Laws (Supp. 1934) \$roo3 (12).

B LA. CODE (Dart, I932) $\$ 844 x$.

${ }^{7} \mathrm{Fla}$. Acts 1935 , c. 17442. 
such an owner at the time of sale, the Trustees have issued a deed to him for approximately the amount of the decree plus a small fee to the Trustees for handling. In several instances lands have been sold to others than the original owners where consent of the latter has been procured. The Trustees have coopperated with the counties and interested parties to restore the lands to the tax books and to the possession of the original owners.

According to a report prepared for the Governor's Office, February I, I933, there was at that time in Florida $16,707,273$ acres covered by state certificates. This represented approximately one-half of the $34,075,907$ acres in the state. It was estimated by the Special Committee on Taxation and Public Debt in Florida, that at the beginning of 1935 the amount of tax-delinquent land had increased to over $18,000,000$ acres. As can be seen from the figures given above, the amount of land now held by the Internal Improvement Fund, 3r,260 acres and 177 lots, is only a very small part of the total tax-delinquent land in Florida.

Technical flaws render valueless the title to most of the 2,000,000 acres of land in Arkansas which tax delinquent owners have failed to redeem after it has been bid in by the state. In Tennessee the law authorizing the state to acquire title to tax delinquent property has become a dead letter as a consequence of official laxity and, lately, because the state's abandonment of the real.property tax has left the counties and municipalities unprepared. Although in Kentucky the state can purchase tax delinquent property, the unvarying policy of that state has been to commit such land to private ownership rather than to vest title in itself.

\section{The Administration of Tax-Reverted Land}

Even those states which can get a good title to tax delinquent land have been hesitant about taking title because of the lack of facilities for administering it. Notable among the states which guarantee clear title to tax-reverted lands and which have also made provision for administering such lands are New York and Michigan. In New York the right of redemption expires one year after the date of sale. ${ }^{8}$ In the forest-preserve counties the tax-title lands pass directly to the state and absolute title is assured. ${ }^{9}$ In other parts of the state delinquent lands go to the counties. ${ }^{10}$

The Hewitt Reforestation Act of $1929^{11}$ authorized the purchase and reforestation of idle and abandoned land outside the forest-preserve counties by the state wherever blocks of 500 acres or more can be acquired, and by the state in coipperation with the counties in which they lie in the case of smaller abandoned tracts. An initial appropriation of $\$ 100,000$ was provided by the Act to inaugurate the work, and in I93I the voters of the state approved a bond issue of $\$ 19,000,000$ to carry it forward. New York thus offers the owner of submarginal land an opportunity to sell it at a nominal price rather than have to sacrifice his entire equity.

In Michigan, the right of redemption expires six months after a deed made to

${ }^{8}$ N. Y. Consor. Laws (Cahill, I930) c. 6r, $\$ \$ 127,152,153$.

Id. 5151.

${ }^{10}$ Ibid.

"Id. c. ro, $\$ 60 a$. 
the state has been recorded in the county in which the land is situated and thereafter the title is absolute. ${ }^{12}$ Land so acquired is classified according to its use capabilities and that not suitable for agriculture and lying adjacent to other state lands is dedicated to state use. The state has already acquired title to about two million acres, most of which is being administered by the state department of conservation as state forests, state game refuges, or state parks.

In Wisconsin, lands that have been delinquent for three years may be deeded to the county. ${ }^{13}$ Counties do not have to foreclose immediately after the expiration of three years, however, the law permitting a deed to be taken any time within 15 years from the date of the tax-sale certificate. Some counties have adopted the policy of acquiring a deed as soon as the redemption period of three years has elapsed. Others attempt to sell the certificates even at less than face value, but the tendency appears to be in the direction of taking title to all lands which may be deeded. Counties are encouraged to list suitable tax-reverted lands under the forest-crop law, and 853,000 acres of county lands had been so listed up to September I, 1933. The state pays to the county ten cents an acre annually for management and exacts 75 per cent of the revenue derived from the sale of timber. Under Wisconsin's county zoning law ${ }^{14}$ a county may exchange tax-reverted lands in unrestricted areas for other lands in areas closed to further settlement.

Legislation has been enacted in Minnesota through which the state may acquire tax-delinquent lands for inclusion in conservation areas. ${ }^{15}$ A fund of $\$ 50,000$ has been appropriated for the acquisition of lands delinquent for three years or more. The owner selling the land must reimburse the local tax districts for back taxes, in whole or in part, and the balance of the proceeds of the sale, if any, goes to the seller.

In Virginia, tax delinquent land formerly could revert to the state but with the abolition of the state property tax there developed some uncertainty whether the county could foreclose on the lien. At any rate, the counties have not done so, and it is estimated that there are fully a million acres subject to reversion. In a recent session, the-legislature, therefore, clarified the law, giving the county the unquestioned right to take title. ${ }^{16}$ As an inducement for the county to do so, another act was passed whereby forest land owned or acquired by a county may be deeded to the state, and the state will return to the county 25 per cent of the gross receipts therefrom. ${ }^{17}$ It is contemplated that the state will block up state forests around these tax-delinquent lands by means of federal loans obtained under the provisions of the Fulmer Act ${ }^{18}$ which authorizes Congress to set up a revolving fund from which loans may be made to the states for the acquisition of forest land. The loan is to be repaid without interest from the proceeds of the forest, fifty per cent of its income to be earmarked for this purpose.

\footnotetext{
${ }^{12}$ Mrch. Consp. Laws (1929) $\$ 3724$.

${ }^{23}$ Wis. Stat. (1933) 575.36.

${ }^{15}$ Minn. Laws I93I, c. 407, 5x, p. 57x.

${ }^{17}$ Ibid.
}

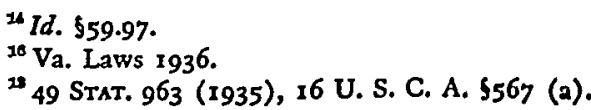


An interesting feature of the Fulmer Act is a provision to the effect that after June 30,1942 no additional lands shall be acquired within a state which has not prior thereto provided by law for the reversion of title to the state or political unit thereof of tax delinquent lands. ${ }^{19}$ Moreover, prior to June 30,1942 preference is to be given to states which provide under their tax-delinquency laws for such reversion of title. ${ }^{20}$

In 1933 there was created in West Virginia a Public Land Corporation in which the title to tax-delinquent lands was to be vested after the expiration of a moratorium declared until December 3r, 1935..$^{21}$ At the present time, the State Auditor, in coöperation with the State Department of Conservation, is engaged in listing and classifying the lands which have been forfeited to the state and not redeemed. Although this inventory has not been completed preliminary estimates place the number of tracts, including city lots, which have reverted to the state at 125,000 . The total acreage involved cannot be determined until duplications and errors have been sifted out.

The title to land reverting as of December 3I, I935 and thereafter becomes absolute and the land can therefore be administered for a public purpose. The Public Land Corporation may acquire from individuals or from the State Commissioner of forfeited lands by purchase, lease or agreement any lands that may be necessary for a public use. For the purpose of consolidating lands either under state or federal administration the corporation may sell, purchase or exchange lands or stumpage. The corporation may also negotiate loans from the United States for the purchase of lands under the Fulmer Act. It has the authority to designate lands to which it has title to such public uses as forestation, stock grazing, agricultural rehabilitation and homesteading, or it may contract or lease them for the proper development of oil, gas, mineral and water rights within or upon them.

All income received from the use of such public lands is to be used solely for the purpose of liquidating the obligations incurred for their acquisition, development and administration. Any net income derived after all indebtedness or other obligations have been discharged is to be paid into the general school fund.

\section{Private Ownership of Land Carries Responsibiuttites}

For one hundred and fifty years the policy of the nation has been to encourage the transfer of land from public to private ownership. This policy unquestionably hastened the occupation and development of an ever-receding frontier. As new territory was occupied new states, new counties and new school districts were formed. Since the property tax was the main reliance of these new units of government, there was always pressure to get every acre of the public domain into private ownership and onto the tax roll. The result was that the poor land as well as the good was sold or homesteaded. Even the forest and mineral lands were sold or given away, and with almost no restrictions on their use. The results of unrestrained

20 Id. 5567 (b) (a).

${ }^{\infty}$ Ibid.

\#W. Va. Acts 1933 (Ext. Sess.) c. 54 . 
exploitation have naturally been forest devastation, soil depletion or exhaustion, and the drying up or pollution of water resources.

The strict logic of the property tax would be to reduce steadily the valuation of a diminishing resource until in the case of badly eroded agricultural land or severely denuded forest land the assessed value for taxes became almost zero. This has not been done very generally because local governments have not wanted to reduce their tax rolls. It may, therefore, be argued that cut-over forest land and worn-out farm land have been over-assessed and that this explains why these kinds of property are delinquent in such volume. Their delinquency, it is claimed, is directly traceable to illegal assessment. As sheer logic the argument is unimpeachable.

But there is another point of view to be considered. The government, that is society collectively, was the first owner of the land. It alienated it to permit private exploitation and profit. Now that the resources have been exploited, frequently to the point where the destruction of the land itself is threatened, there ought to be an easy way for the government to recover the land in the interest of conservation. Purchase is preferable to confiscation through tax delinquency, but if the owner will neither protect the land nor bear the minimum tax imposed for the privilege of owning and controlling a portion of the earth's surface confiscation is justifiable.

It is not in the interest of sound land use nor fair to posterity to remit the tax on land which is yielding no present income. Neither is it in the interest of sound land use to place the tax so low that the land can be held purely for speculation, deteriorating in quality and contributing little to the nation's support. An annual tax of a few cents an acre on even the poorest land ought to be demanded for the mere privilege of ownership, and failure to pay this minimum tax ought to be sufficient justification for the state to demand the forfeiture of title. 